\title{
Molecular Study of Antiviral Compound of Indonesian Herbal Medicine as 3CLpro and PLpro Inhibitor in SARS-COV-2
}

\author{
Baiq Ressa Puspita Rizma, ${ }^{[a]}$ Yek Zen Mubarok, ${ }^{[b]}$ Dian Fathita Dwi Lestari, ${ }^{\left[{ }^{[c]}\right.}$ Agus Dwi Ananto ${ }^{* d]}$ \\ [a] Pharmacy Departement \\ Faculty of Medicine, Mataram University, Indonesia \\ JI. Majapahit No. 62 Mataram Nusa Tenggara Barat, 83125, Indonesia \\ E-mail: baiqressapuspitarizma@gmail.com \\ [b] Pharmacy Departement \\ Faculty of Medicine, Mataram University, Indonesia \\ JI. Majapahit No. 62 Mataram Nusa Tenggara Barat, 83125, Indonesia \\ E-mail: zenmubarok@gmail.com \\ [c] Pharmacy Departement \\ Faculty of Medicine, Mataram University, Indonesia \\ JI. Majapahit No. 62 Mataram Nusa Tenggara Barat, 83125, Indonesia \\ E-mail: dianfathitadwilestari@gmail.com \\ [d] Pharmacy Departement \\ Faculty of Medicine, Mataram University, Indonesia \\ JI. Majapahit No. 62 Mataram Nusa Tenggara Barat, 83125, Indonesia \\ E-mail: agus da@unram.ac.id
}

DOI: $\underline{10.29303 / a c a . v 4 i 2.74}$

Article info:

Received 31/07/2021

Revised 04/10/2021

Accepted 29/10/2021

Available online 01/11/2021
Abstract: Rapid transmission of COVID-19 disease and the fatal effects lead researchers to use various ways to find potential anti-COVID-19 compounds, including modern approaches. Molecular docking is one of the methods used to analyze antiviral compounds and their molecular target from Indonesian herbs believed to have properties as anti-COVID-19. This study aims to analyze antiviral compounds from 5 herbs potent inhibitors of PLpro and 3CLpro, both non-structural proteins in SARS-CoV-2, using a molecular docking approach using PLANTS. Remdesivir triphosphate, the active metabolite of remdesivir, was used as the comparison compound in studies. The results showed docking scores obtained from interactions between natural ligands, remdesivir triphosphate, curcumin, demethoxycurcumin, bisdemethoxycurcumin, luteolin, apigenin, quarcetin, kaempferol, formononrtin-7-O-glucoronide, androgafolide, and neoandrogafolide with PLpro are as follows $-111,441,-103,827,-103,609,-102,363,-100,27,-$ $79,6655,-78.6901,-80.9337,-79.4686,-82.1124,-79.1789$, and -97.2452 .The combination of quercetin, neoandrographolide, bisdemethoxycurcumin, demetoxycurcumin, and curcumin showed a synergy effect by reducing its docking score. Meanwhile its interaction with the protein 3CLpro showed docking score for those compounds as follows $64.0074,-86.1811,-81.428$, 87.1625, -78.2899, -73.4345,-70,3368, -71.5539, -68.4321, -72.0154, -75.9777 and -93.7746. The combination between andrographolide, neoandrographolide, bisdemethoxycurcumin, demetoxycurcumin, and curcumin, also shows a synergy effect in 3CLpro allow them to reduce the docking score. This study concludes that curcumin was the most potent compound that acts as a PLpro inhibitor based on a docking score of -103,609. In contrast, all the compounds have the potential to inhibit 3CLpro with demethosxycurcumin and neoandrogafolide as the most potent compound with a docking score $-87,126$ and -93.7746 .

Keywords: Indonesian herbs, antiviral compounds, anti-COVID-19, molecular docking, Plants

Citation: Rizma, B. R. P., Mubarok, Y. Z., Lestari, D. F. D., Ananto, A. D., (2021). Molecular Study of Antiviral Compound of Indonesian Herbal Medicine as 3CLpro and PLpro Inhibitor in SARS-COV-2, Acta Chimica Asiana, 4(2), 127-134. DOI: 


\section{INTRODUCTION}

Corona Virus Disease 2019 (COVID-19) is a respiratory system disease caused by Severe Acute Respiratory Syndrome Corona Virus-2 (SARS-CoV-2). The disease affected the entire world include Indonesia. WHO declared COVID-19 to become a worldwide pandemic in March 2020 [1]. The COVID-19 spreads through droplets, saliva, or release from the nose of an infected individual after sneezing or coughing [2]. According to WHO, from January 2020 to July 2021, there have been 2.950.058 confirmed cases of COVID-19 in Indonesia [3]. The high number of confirmed cases encourages the government to continue suppressing the spread of COVID-19 in Indonesia. Some of the government's efforts are the implementation of lockdown, tightening health protocols, etc.

Individuals that confirmed mild symptoms suggested having self-isolation at home. A self-isolation and tracing contact is some effort has been made to reduce the transmission of COVID-19. There are no specific drugs to treat or prevent COVID-19. In their current treatment, medical professionals use a broadspectrum antiviral named Remdesivir as a treatment for COVID-19. Remdesivir, known as GS-5734 is a prodrug of an adenosine analog expanded to respond to the Ebola outbreak in West Africa [4]. There are two nonstructural proteins, SARS-CoV-2, such as papain-like protease (PLpro) as a virulence factor of SARS-CoV-2, and $3 \mathrm{C}$-like protease (3CLpro) are believed used for replicating new viruses [5]. SARS-CoV-2 replications according to viral RNA-dependent RNA polymerase $\mathrm{RdRp}$ is the most credible target of the investigational nucleotide analog Remdesivir (RDV) [6,7].

Indonesian Food and Drug Administration (BPOM) mentioned that several Indonesian medicinal plants contained an antiviral activity compound that can be used to treat infections of COVID-19. The mentioned plants are sambiloto (Andrographis paniculata), turmeric (Curcuma longa), guava (Psidium guajava), Curcuma (Curcuma xanthorrhiza), and meniran (Phyllanthus niruri) [8]. There are some researches have been done to prove the plants have antiviral activity compounds. These compounds actively inhibit two non-structural proteins in SARS-CoV-2. Based on a scientific study, quercetin in guava can inhibit papainlike protease (PLpro) in SARS-CoV-2 [9], curcumin in Curcuma longa can inhibit the 3C-like protease (3CLpro) of SARS-CoV-2 [10].

The plants, as mentioned before, can be an alternative drug for COVID-19. Based on the context of the researchers aimed to approve the potency of several Indonesian medicinal plants to inhibit PLpro and $3 \mathrm{CL}$ pro, two main non-structural proteins of SARS-CoV2 using a molecular docking method. Molecular docking is routinely used for understanding drug-receptor interaction. Molecular docking gives helpful information about drug-receptor interactions. It is often used to predict the binding direction of the ligands of drug candidates to their protein targets to predict the affinity and activity of the ligands [11]. Molecular docking has more advantages in this pandemic era. It is more efficient to use. Molecular docking can be done online so that it will lessen the physical contact between the researchers. This study aims to identify the potent compounds as inhibitors PLpro and 3CLpro.

\section{MATERIALS AND METHODS \\ Software and Hardware}

There is three software used in this research: marvinSketch 5.2.6 from ChemAxon, YASARA View 19.12.14 from YASARA Bioscience, and PLANT (Protein-Ligand Ant System) 64 bit from CHemAxon.

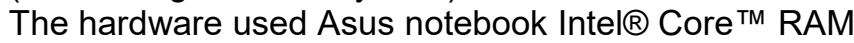
4.00 GB, Operation system Windows 10, 64-bit operating system.

\section{Ligands}

The two-dimension structure of each ligand in this research was downloaded from the PubChem database. It was reformed into a three-dimension structure using MarvinSketch to get the best conformation. The ligands were divided into two types: standard ligand and test ligand. Remdesivir triphosphate (PubChem ID 56832906) as the standard ligand. The test ligands were andrographolide (5318517), curcumin (965516), kaemferol (5280863), bisdemethoxycurcumin

(5469424),

neoandrographolide (9848024), quercetin (5280343), and formononetin-7-glucuronide (71316927).

\section{Receptors}

The receptors used in this research were two nonstructural proteins of SARS-CoV-2, 3CLpro (PDB ID 5R7Y)19 and PLpro (3E9S). It was downloaded from Protein Data Bank [12].

\section{Docking protocol}

There are three steps docking protocol used in this research, first preparation of target protein and native ligand, second docking protocol validation, and third test ligand docking.

\section{Preparation of native ligand and target protein}

Preparation of native ligand and target protein using YASARA view. This step aims to delete the native ligand of each protein.

\section{Docking protocol validation}

Docking protocol validation aims to get an RMSD (Root Median Square Deviation) value using YASARA view by re-docking the native ligand to its protein. Docking protocol validation is accurate if the RMSD value is less than 2 amstrong [13].

\section{Test ligand docking}

Test ligand docking was done by typing the commands in cmd.exe using PLANTS. The active site of PLpro and 3 CLpro was docked to the test ligand. PLANTS will read 
the command to get the best docking score. The best docking score would be contrasted to the best score of the naïve ligand.

\section{Docking protocol combination}

The docking protocol combination aims to find the synergic relation between the compounds to obtain sufficient stability to bind to each target protein. Docking protocol combination was done by arranging the compounds according to the average docking score. The compounds with the highest docking score and the target protein are saved in a file named protein.mol2 and would be docked to the compounds with a lower docking score.

\section{RESULTS AND DISCUSSION}

\section{Validation of Docking Protocol}

The validation protocol is a step to ensure the docking protocol has been validated to be used for the following docking process. RMSD (Root Mean Square Deviation) is one validation parameter obtained from redocking the native ligand with the protein. A docking protocol was stated as a valid protocol if the RMSD value $<2 \AA$ [14]. Redocking of 5-amino-2-methyl-N-[(1R)-1-naphthalen1-ylethyl] benzamide -the native ligand of PLpro- to protein PLpro showed the RMSD value was $0,5707 \AA$. Whereas 5-amino-2-methyl- $N$-[(1R)-1-naphthalen-1ylethyl] benzamide - the native ligand of 3CLpro - to protein 3CLpro showed, the RMSD value was $1.5525 \AA$.

\section{Docking in Plpro}

Among 10 test ligands, the docking score of curcumin ($103,609)$ is almost equal to remdesivir triphosphate (103,827) (Shown in Table 1). This result indicates that curcumin forms a stable interaction and a good affinity and remdesivir triphosphate in PLpro. Based on this result, we can conclude that curcumin has the potential as an inhibitor of PLpro.

Curcumin is usually found in Curcuma longa L. and Curcuma xanthorrhiza Roxb. These two plants have many curcuminoid: curcumin, demethoxycurcumin dan bisdemethoxycurucumin (Shown in Figure 1).

Curcumin, demethoxycurcumin, and bisdhemetoksicurucumin have differences in the presence of methoxy group in both aromatic rings of the compounds. Curcumin has pharmacophores responsible for its biological activities, such as hydroxyl groups $(\mathrm{OH})$ and methoxy groups $(\mathrm{OCH} 3)$ in its aromatic rings. While demethoxycurucummin lost one of the methoxy groups and bisdemethoxycurucumin lost both methoxy groups.

The existence of methoxy group is predicted to have an essential role in helping to stabilize the affinity and chemical bond between the compounds on PLpro. The methoxy group in curcumin form an interaction with amino acids such as Met170 and Tyr155. While demethoxycurcumin, which has one methoxy group, only forms an interaction with Met170. On the other hand, bisdemethoxycurcumin that does not have any methoxy group cannot form an interaction or form a chemical bond to both Met170 or Tyr155. Thus, the loss of methoxy group in demethoxycurucumin and bisdemethoxycurcumin leads to a decrease in chemical bond stability and affinity of the compound to the target protein, resulting in a more excellent docking score compare to curcumin (Shown in Figure 1).

Table 1. Docking Score of Test Ligand to PLpro

\begin{tabular}{ccc}
\hline & Docking Score with & $\begin{array}{c}\text { Remdesivir } \\
\text { PLpro }\end{array}$ \\
\cline { 3 - 3 } Compounds & -103.609 & $=$ \\
& -102.363 & $>$ \\
Curcumin & -100.271 & $>$ \\
Demethoxycurcumin & -79.6655 & $>$ \\
Bisdhemetoxycurcumin & -78.6901 & $>$ \\
Luteolin & -80.9337 & $>$ \\
Apigenin & -79.4686 & $>$ \\
Quercetin & -82.1124 & $>$ \\
Kaempferol & -79.1789 & $>$ \\
Formononetin 7-O- & -97.2452 & $>$ \\
Glucoronida & & $>$ \\
Androgapholide & &
\end{tabular}


Previous in silico research with AutoDock Tools1.5.6 also shown that curcumin have the smallest free binding energy $(\mathrm{kcal} / \mathrm{mol})$ with PLpro $(-8,45)$ compared to other target such as ACE2 $(-7,99)$, TMPRSS2 $(-7,19)$, RdRp($5,3)$, and 3CLpro $(-7,24)[15]$.

Based on the docking score, there are 5 compounds with the smallest docking score. The compounds are

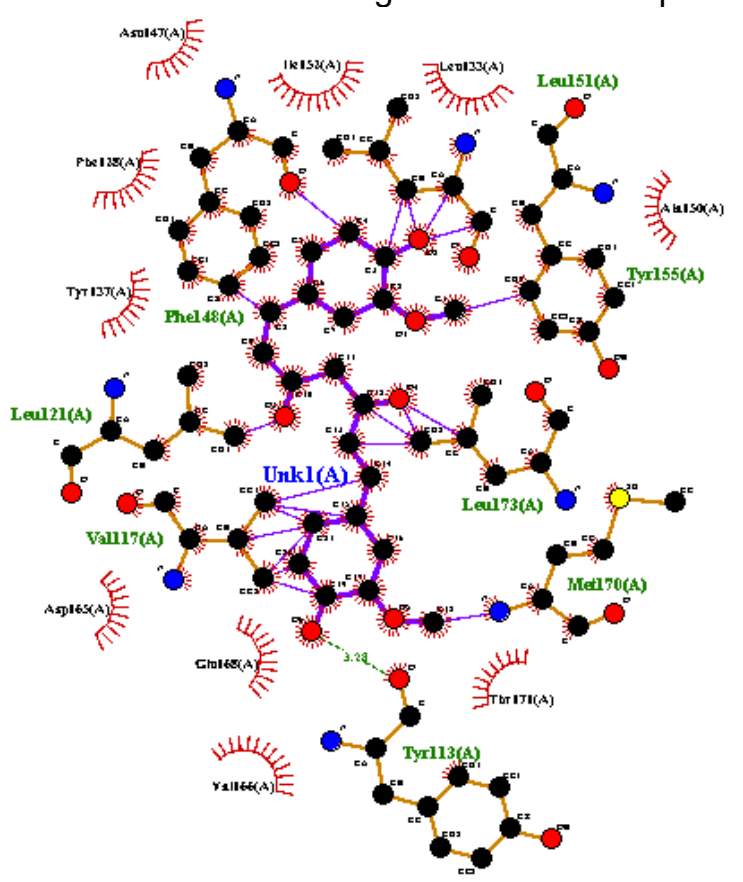

Kurkumin 3e9s
Quercetin $(Q), \quad$ Neoandrographolide $\quad(N)$, Bisdemethoxycurcumin (B), Demetoxycurcumin (D), and Curcumin (C). We try to combine these compounds to identify any difference between a single compound and the combination as PLpro inhibitor based on its docking score.

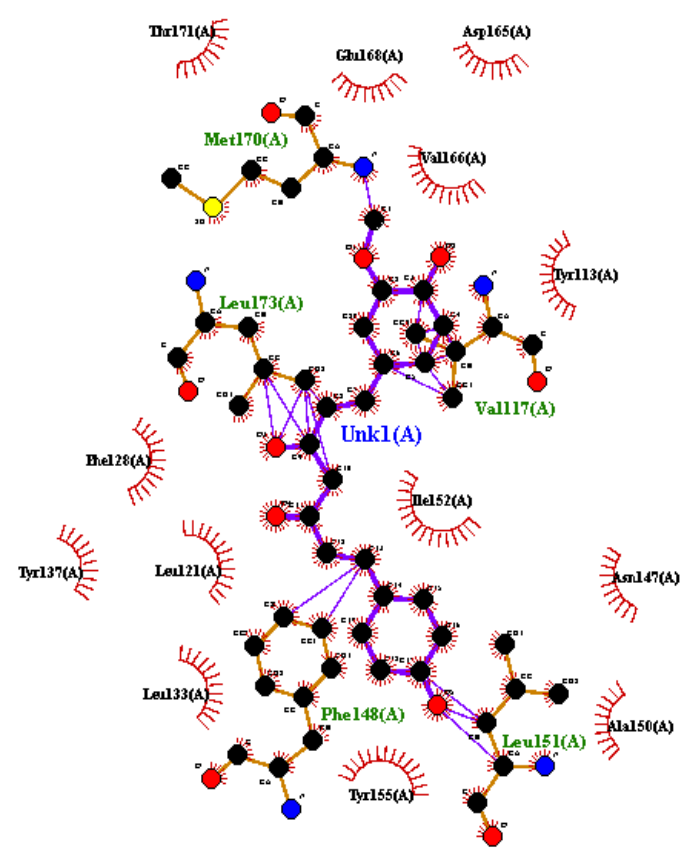

Demetoksikurkumin_3e9s

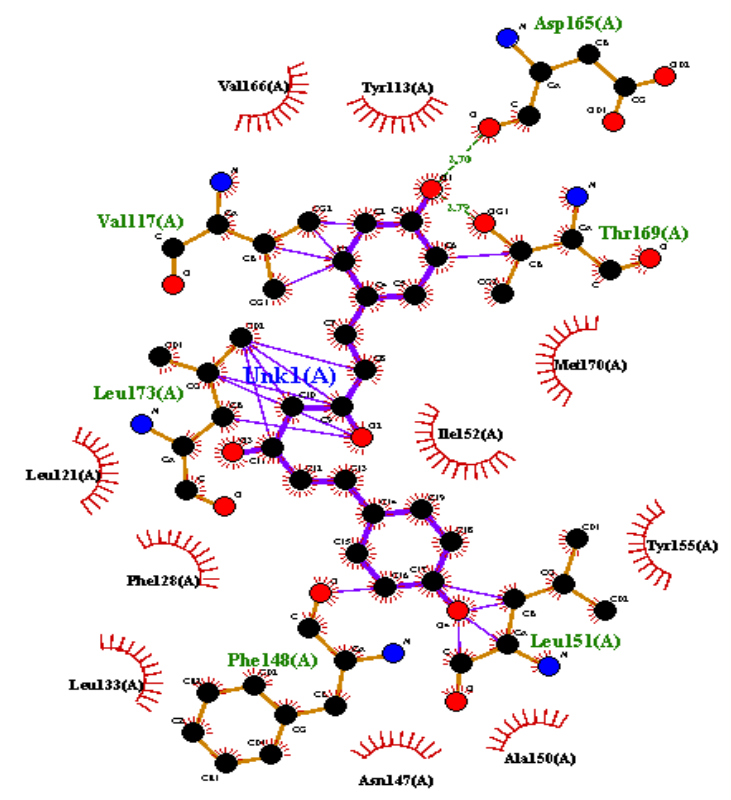

bisdemetoksikurkumin_3e9s

Figure 1. Visualisation of Curcumin, Demethoxycurcumin, and Bismedethoxycurcumin in interaction with PLpro using LigPlot. 
Among 22 combination variation, there is 12 combination that has a smaller docking score compared to curcumin (-103.609) and remdesivir triphosphate ($103,807)$. From these results, we can conclude that there are synergic effects between the compounds to increase the stability of chemical bonds and increase their affinity to PLpro as a result of decreasing in docking score (Shown in Table 2)

Table 2. Docking Score of Combination in PLpro
Table 3. Docking Score of Test Ligand to 3CLpro

\begin{tabular}{lcc}
\hline \multirow{1}{*}{ Compounds } & Docking & Remdesivir \\
& score with & Tp \\
\cline { 3 - 3 } & 3CLpro & $(-86,1811)$ \\
\hline Curcumin & $-81,428$ & $>$ \\
Demethoxycurcumin & $-871,625$ & $<$ \\
Bisdemethoxycurcumin & $-782,899$ & $>$ \\
Luteolin & $-734,345$ & $>$ \\
Apigenin & $-703,368$ & $>$ \\
Quercetin & $-715,539$ & $>$ \\
Kaempferol & $-684,321$ & $>$ \\
Formononetin 7-O- & $-720,154$ & $>$ \\
Glukoronida & $-759,777$ & $>$ \\
Androgapholide & $-937,746$ & $<$ \\
Neoandrogapholide & -937
\end{tabular}

\begin{tabular}{lll}
\hline \multicolumn{1}{c}{ Compounds } & $\begin{array}{c}\text { Docking } \\
\text { Score }\end{array}$ \\
\hline & QNBDK & -105.93 \\
\hline & QDK & -105.887 \\
\hline QNDK & -105.871 \\
\cline { 2 - 3 } BK & -105.781 \\
\cline { 2 - 3 } Combination & QBDK & -105.754 \\
\cline { 2 - 3 } & QBK & -105.738 \\
\cline { 2 - 3 } & NK & -105.728 \\
\cline { 2 - 3 } & NBDK & -105.713 \\
\cline { 2 - 3 } & QNBK & -105.645 \\
\cline { 2 - 3 } & DK & -105.567 \\
\cline { 2 - 3 } & BDK & -105.436 \\
\cline { 2 - 3 } & QK & -104.518 \\
\cline { 2 - 3 } & QNK & -104.318 \\
\cline { 2 - 3 } & BDK & -103.856 \\
\hline \multirow{5}{*}{ Cingle } & Curcumin & -103.609 \\
\cline { 2 - 3 } & Demethoxycurcumin & -102.363 \\
\cline { 2 - 3 } & Bisdemethoxycurcumin & -100.271 \\
\cline { 2 - 3 } & Neoandrogapholide & -97.2452 \\
\cline { 2 - 3 } & Quarcetin & -80.9337 \\
\hline
\end{tabular}
Symbol Explanation: Smaller than ( <), Bigger than (>), Equal as (=)

Meanwhile, curcumin only forms 11 hydrophobic contacts with amino acids residue in 3Clpro (Shown in Figure 2). The hydrophobic contact helps the nonpolar site of demethoxycurcumin to bind with the nonpolar site of 3CLpro in a watery environment, the movement of the water when the two nonpolar sites try to bound reduces its energy as the result of decreasing its docking score [17].

This research is supported by research conducted by Khaerunnisa (2020), showing that based on in silico research with AutoDock Vina, demethoxycurcumin has a smaller free energy binding $(-7,99 \mathrm{kcal} / \mathrm{mol})$ than curcumin $(-7,05 \mathrm{kcal} / \mathrm{mol})$ as 3 CLpro inhibitor [18].

The interaction of neoandrogafolide with 3CLpro showed results in contrast to their interactions with PLpro.Neoandrogafolide (-93.7746), categorized as a compound with good bond stability and affinity at 3CLpro because it has a docking score that is smaller than the natural ligands (-64.0074) and remdesivir triphosphate (-86.1811).The interaction of androgafolide compounds $(-75.9777)$ with the protein 3CLpro showed the compound had no better bond stability and affinity than neoandrografolide, despite having a lower docking score compared to natural ligands (-64.0074), but still larger than remdesivir triphosphate (-86.1811).

Andrografolide and Neoandrografolide differ in terms of the addition of glucose groups in neoandrografolide, hydroxyl groups in glucose structure are thought to play an essential role in compound activities. Existing glucose groups help neonadrografolide bind to amino acids such as Val114, Phe113,Ser113,Phe150, Leu115, Gly14, and Val148, which in andrografolide are not found. Although similarities with natural ligands and remdesivir triphosphate are still quite far away in terms of docking scores, neoandrografolide has good bonding stability and affinity on 3Clpro (Shown in Figure 2). 


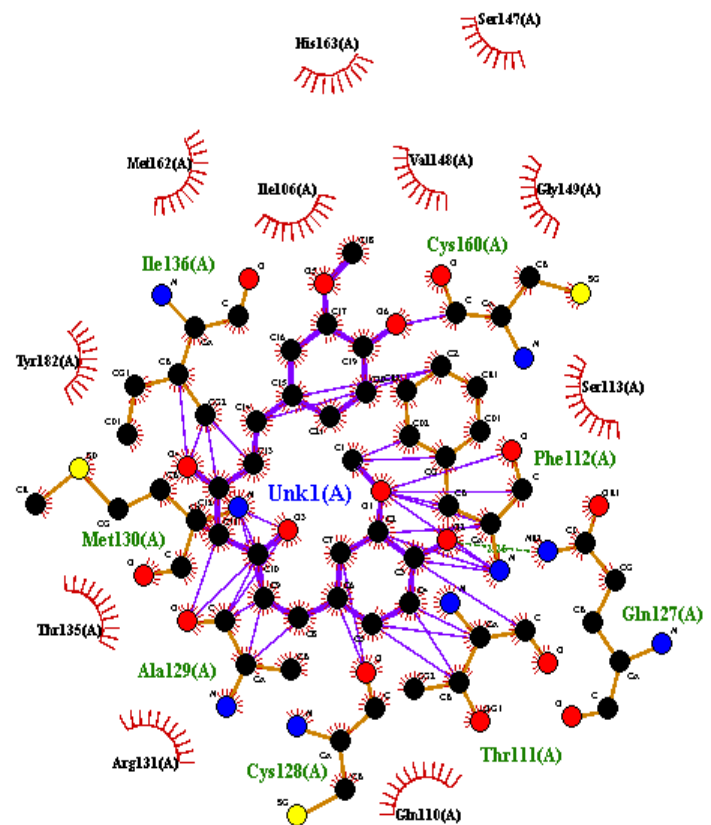

Kurkumin_5r7y

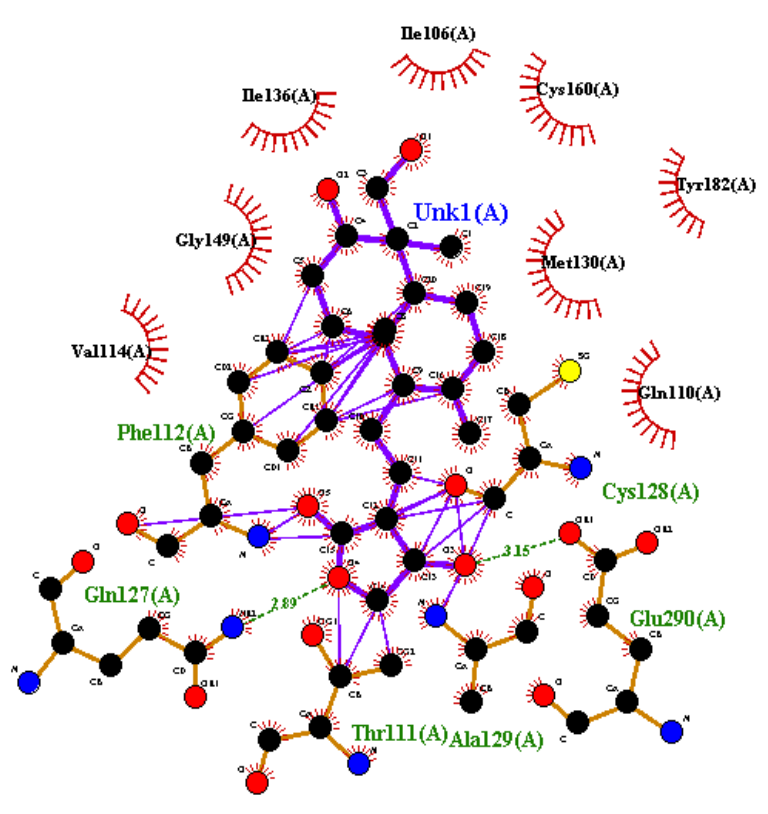

Androgafolida_5r7y

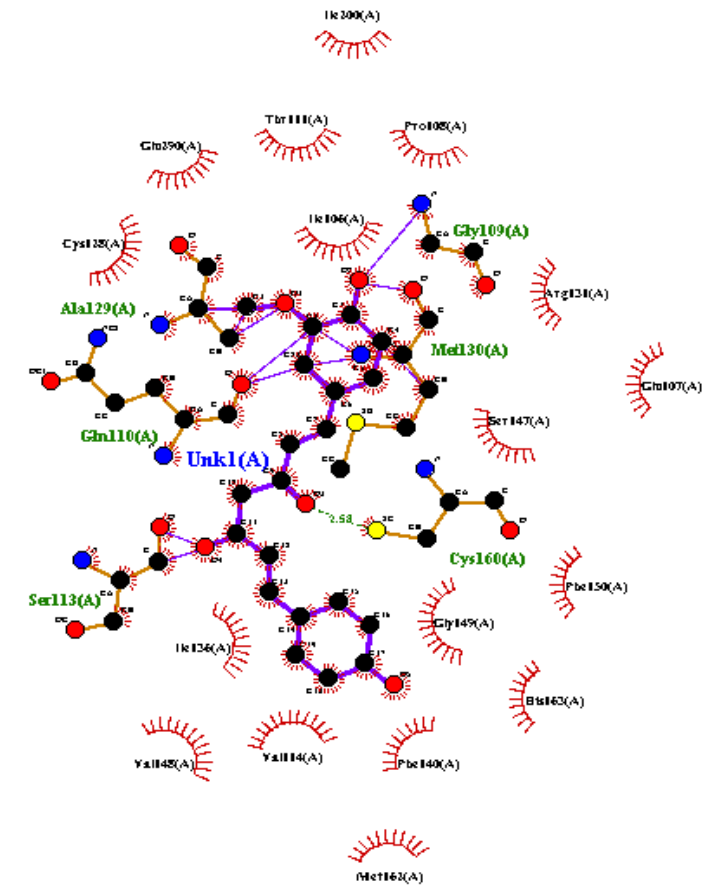

demetoksikurkumin_5r7y

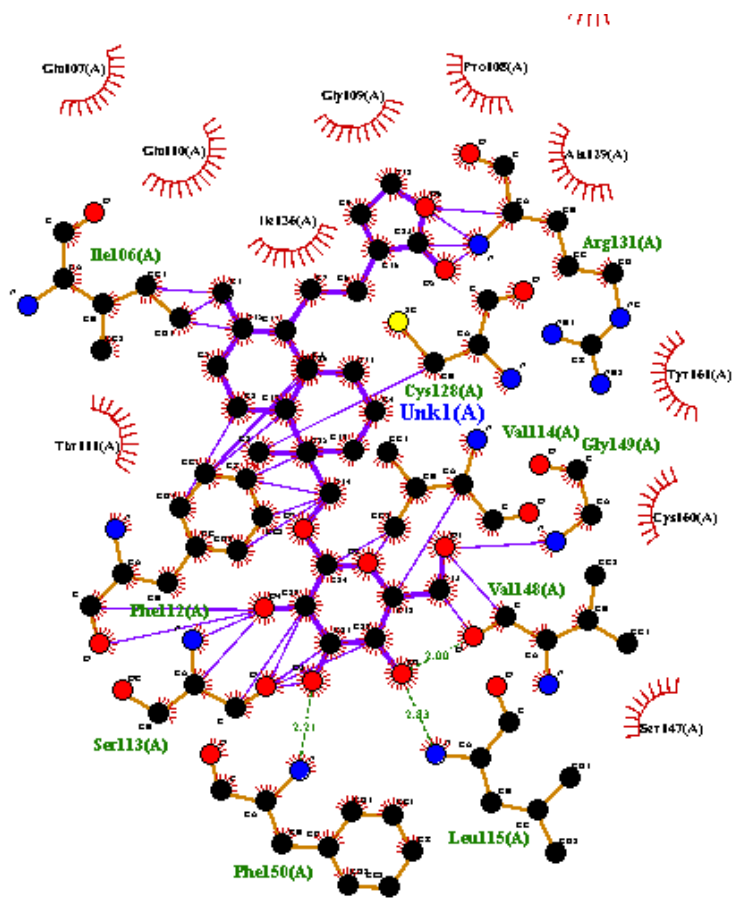

Neoandrogafolida_5r7y

Figure 1. Visualisation of Curcumin, Demethoxycurcumin, Andrografolide and Neoandrografolide in interaction with 3CLpro using LigPlot

This result was supported by previous in silico research using AutoDock that shown among 4 andographis paniculata main compounds such as andrographolide (AGP1), 14-deoxy 11,12-didehydro andrographolide (AGP2), neoandrographolide (AGP3), and 14-deoxy andrographolide (AGP4). AGP3 has the smallest free binding energy $(\mathrm{kcal} / \mathrm{mol})$ in interaction with 3CLpro $(-31,4)$ 
compare to other target such as PLpro $(-28,5), \operatorname{RdRp}$ $(-17,1)$ and Spike $(-23,9)[19]$.

Table 4. Docking Score of Combination in 3CLpro

\begin{tabular}{|c|c|c|}
\hline & Compounds & $\begin{array}{l}\text { Docking } \\
\text { Score }\end{array}$ \\
\hline \multirow{15}{*}{$\begin{array}{l}\text { Combinati } \\
\text { on }\end{array}$} & KDN & -93.7718 \\
\hline & ABDN & -93.771 \\
\hline & DN & -93.7631 \\
\hline & AND & -93.7566 \\
\hline & AKDN & -93.7564 \\
\hline & BKDN & -93.7503 \\
\hline & $\mathrm{KN}$ & -93.746 \\
\hline & AKN & -93.7303 \\
\hline & $\mathrm{BN}$ & -93.728 \\
\hline & BDN & -93.7276 \\
\hline & AN & -93.7272 \\
\hline & $\mathrm{BKN}$ & -93.7221 \\
\hline & $A B N$ & -93.7212 \\
\hline & ABKDN & -93.6937 \\
\hline & ABKN & -93.6872 \\
\hline \multirow{5}{*}{ Single } & Neoandrogapholide & -93.7746 \\
\hline & Demethoxycurcumin & -87.1625 \\
\hline & Curcumin & -81.428 \\
\hline & $\begin{array}{l}\text { Bisdemethoxycurcu } \\
\text { min }\end{array}$ & -78.2899 \\
\hline & Androgapholide & -75.9777 \\
\hline
\end{tabular}

Based on the docking score of 10 test ligands with 3 CLpro there are 5 compounds with the smallest docking score. The compounds are andrographolide (A), Bisdemethoxycurcumin (B), curcumin (C), demethoxycurcumin (D), and Neoandrographolide $(\mathrm{N})$.

Among 22 variations of combination, 15 combinations have a smaller docking score compared to remdesivir triphosphate, but when compared to neoandrographolide, there is no significant difference in the docking score. So we can conclude that the synergy effect between these compounds has no big impact to increase its inhibitory effect in 3CLpro.

This research result is just a prediction with computer simulation help. It still needs further research, such as in vitro and in vivo, to validate these results. This research also has some limitations. This research didn't perform a quantitative structure-activity relationship, so we can't identify the compound's steric, hydrophobic and electronic factors. We can't predict the pharmacokinetic properties of the compounds like the molecular dynamics method. This research also only uses one molecular docking application to perform the docking process. Docking with the different applications may lead to different results because of the different algorithms used.

\section{CONCLUSION}

In conclusion, curcumin is an antiviral compound that has potency as PLpro inhibitor. Meanwhile, combinations showing potency as PLpro inhibitors are QNBDK, QDK, QNDK, BK, QBDK, QBK, NK, NBDK, QNBK, DK, NBK, QK, QNK, and BDK. Demethoxycurcumin and neoandrografolide are antiviral compounds that have the potency of 3 CLpro inhibitor. Meanwhile, a combination that shows a potency as 3 CLpro inhibitor is $A N, B N, K N$, $D N, A K N, A D N, B K N, B D N, K D N, A B K N, A B D N$, $A K D N, B K D N$, and $A B K D N$.

\section{REFERENCES}

[1] Scafti, O. T. (2021). New Hopes for Drugs against COVID-19 Come from the Sea. Department of Pharmacy, School of Medicine and Surgery, University of Naples Federico, Italy.

[2] Pant, S., Singh, M., Ravichandiran, V., Murty, U. S. N., \& Srivastava, H. K. (2020). Peptidelike and small-molecule inhibitors against Covid-19. Journal of Biomolecular Structure and Dynamics, 1-15.

[3] WHO Coronavirus Disease (COVID-19) Dashboard.

[4] Hendaus, M, A. (2020). Remdesivir in the trearment of coronavirus disease 2019 (COVID-19): a simplified summary. Journal of Biomolecular Structure and Dynamics.

[5] Wrapp, D., Wang, N., Corbett, K. S., Goldsmith, J. A., Hsieh, C.-L., Abiona, O., Graham, B. S., \& McLellan, J. S. (2020). Cryo-EM structure of the 2019-nCoV spike in the prefusion conformation. Science (New York,N.Y.), 367(6483), 1260-1263.

[6] Agostini, M. L., Andres, E. L., Sims, A. C., Graham, R. L., Sheahan, T. P., Lu, X., Smith,E. C., Case, J. B., Feng, J. Y., Jordan, R., Ray, A. S., Cihlar, T., Siege, I D., Mackman, R. L., Clarke, M. O., Baric, R. S., \& Denison, M. R. (2018). Coronavirus susceptibility to the 
antiviral remdesivir (GS-5734) is mediated by the viral polymerase and the proofreading exoribonuclease. $m B i o, 9(2), 1-15$.

[7] Elfiky, A. A., \& Azzam, E. B. (2020). Novel guanosine derivatives against MERS CoV polymerase: An in silico perspective. Journal of Biomolecular Structure and Dynamics, 1-9.

[8] Badan Pengawas Obat dan Makanan Republik Indonesia. Pedoman Penggunaan Herbal dan Suplemen Kesehatan dalam Menghadapi COVID-19 di Indonesia. Jakarta: Badan Pengawas Obat dan Makanan Republik Indonesia. (2020).

[9] Park JY, Yuk HJ, Ryu HW, Lim SH, Kim KS, Park $\mathrm{KH}$, et al. Evaluation of polyphenols from Broussonetia papyrifera as coronavirus protease inhibitors. J Enzyme Inhib Med Chem. 2017;32(1):504-15.

[10] Jena AB, Kanungo N, Nayak V, Chainy GBN. (2021). Dandapat J. Catechin and curcumin interact with $S$ protein of SARS-CoV2 and ACE2 of human cell membrane: insights from computational studies. Sci Rep, 11(1), 2043.

[11] Malau, N. D., \& Azzahra, S. F. (2020). Analysis Docking Of Plasmodium Falciparum Enoyl Acyl Carrier Protein Reductase (Pfenr) With Organic Compunds From Virtual Screening Of Herbal Database. Acta Chimica Asiana, 3(1), 127-134.

[12] Douangamath A, Fearon D, Gerhtz $P$, Krojer T, Lukacik P, Owen CD, et al. Crystallographic and electrophilic fragment screening of the SARS-CoV2 main protease. (2020). Nat Commun, ,11(1), 5047.

[13] Castro-Alvarez A, Costa AM, Vilarrasa J. The Performance of Several Docking Programs at Reproducing Protein-Macrolide-Like Crystal Structures. (2017). Molecules. 22(1), 136.

[14] Purnomo, H. (2013). Kimia Komputasi Untuk Farmasi dan IImu Terkait: Uji In Siliko Senyawa Anti Kanker. Yogyakarta. Pustaka Pelajar.

[15] Laksmiani NPL, Larasanty LPF, Santika AAGJ, Prayoga PAA, Dewi AAIK, Dewi NPAK. (2020). Active Compounds Activity from the Medicinal Plants Against SARS-CoV-2 using in Silico Assay. Biomed Pharmacol J, 13(2), 873-81.

[16] Arwansyah \& Hasrianti. (2014). Simulasi Molecular Docking Senyawa Curcumin dan Analognya sebagai Selective Androgen Receptor Modulators (SARMs) pada Kanker
Prostat. Jurnal Dinamika, 5(2), 61.

[17] Siswandono. (2017). Kimia Medisinal Edisi Kedua Jilid 1. Surabaya. Airlangga University Press. Khaerunnisa, S., Kurniawan, H., Awaluddin, R., dan Suhartati, S. (2020). Potential Inhibitor of COVID-19 Main Protease ( $M$ pro ) from Several Medicinal Plant Compounds by Molecular Docking Study. Preprints.

[18] Khaerunnisa, S., Kurniawan, H., Awaluddin, R., dan Suhartati, S., (2020). Potential Inhibitor of COVID-19 Main Protease ( $\mathrm{M}$ pro ) from Several Medicinal Plant Compounds by Molecular Docking Study. Preprints,p.1-14.

[19] Murugan NA, Pandian CJ, Jeyakanthan J. Computational investigation on Andrographis paniculata phytochemicals to evaluate their potency against SARS-CoV-2 in comparison to known antiviral compounds in drug trials. $J$ Biomol Struct Dyn, 2020, 1-12. 